\author{
Тюхтій М. В., доктор економічних наук, \\ Пономаренко О. Г., кандидат економічних наук \\ Полтавська державна аграрна академія
}

\title{
ЗАГАЛЬНОВИРОБНИЧІ ВИТРАТИ: КОНЦЕПТУАЛЬНІ АСПЕКТИ ВІТЧИЗНЯНОГО ТА ЗАРУБІЖНОГО ДОСВІДУ ОБЛІКОВОГО ВІДОБРАЖЕННЯ
}

Повне визнання, розподіл та облікове відображення загальновиробничих витрат має безпосередній вплив на достовірність визначення собівартості, що корелює з показниками результатів діяльності підприємства. Методичні труднощі для практикуючого бухгалтера становить прочес віднесення загальновиробничих витрат до постійних $і$ змінних, оскільки цей поділ в окремих ситуаціях має ознаки умовного. Це ж стосується й визначення показника «нормальна потужність». Вітчизняні та зарубіжні наукові розробки з означеної проблематики стосуються, передусім, вибору оптимальної бази розподілу загальновиробничих витрат. Дослідження проводилися у напрямі порівняльного аналізу різних варіантів баз розподілу витрат та їх адаптащіï до специфіки виробничого процесу в окремих галузях економіки. Увага також надається методичним підходам включення загальновиробничих витрат у собівартість реалізації за умов визначення ї̈ за нормами П(С)БО 16 «absorption cost» та згідно з популярним у розвинених зарубіжних країнах підходом «direct-costing», а також у світлі вимог податкового законодавства.

Ключові слова: витрати, непрямі витрати, загальновиробничі витрати, база розподілу, постійні та змінні витрати.

Постановка проблеми. Загальновиробничі витрати мають значну питому вагу у загальній структурній побудові витрат основної діяльності, об'єднуючи різні за функціональними напрямами витрати. Об' єктивною є потреба оптимізації їх розмірів та удосконалення методичного обгрунтування включення до собівартості для найбільш достовірного формування цього ключового у конкурентній ринковій боротьбі показника. Наведені аргументи актуалізують побудову раціональної системи управління такими витратами за допомогою належної організації та методики їх облікового визнання, відображення, розподілу й аналізу з урахуванням особливостей економічного середовища і специфіки галузі аграрного виробництва.

Аналіз останніх досліджень i публікацій, у яких започатковано розв'язання проблеми. Науковці, досліджуючи методологічні аспекти обліку загальновиробничих витрат, насамперед надають увагу питанням термінології, тобто визнання.
На думку Л. К. Сук, загальновиробничі витрати - це «непрямі витрати, пов'язані з організацією виробництва і керівництвом цехами, бригадами, відділеннями та іншими структурним підрозділами підприємства, такі витрати раніше називали цеховими» [2].

Бутинець Ф. Ф. під загальновиробничими витратами розуміє витрати з обслуговування виробництва й управління роботою цехів та інших підрозділів основних і допоміжного виробництва [2].

Так, за результатами поглибленого термінологічного аналізу досліджуваної дефініції, О. М. Мазуренко стверджує, що «відсутність чіткого визначення поняття «загальновиробничі витрати» призводить до некоректного віднесення їх до складу витрат, що за своєю економічною природою не належать до загальновиробничих. Тому для розкриття економічної суті, значення та ролі досліджуваних витрат запропоновано вважати загальновиробничими витрати цехів, дільниць $\mathrm{i}$ підрозділів на організацію та управління процесом виробництва, витрати на утримання й експлуатацію машин та обладнання, будівель, споруд, які не можна прямо віднести на конкретний об'єкт витрат [3]».

Обгрунтована класифікація та визначення груп загальновиробничих витрат підвищує ступінь їх однорідності й, водночас, якість і грамотність їх подальшого опрацювання.

Окремі науковці, в тім числі Т. Ю. Кодимська, пов'язують класифікацію загальновиробничих витрат та деталізацію субрахунків їх синтетичного обліку. Зокрема, пропонуються до відкриття наступні субрахунки, що відповідатимуть класифікаційним групам загальновиробничих витрат: 911 «Витрати на утримання та експлуатацію виробничого обладнання»; 912 «Витрати на утримання й експлуатацію виробничого приміщення»; 913 «Транспортні витрати»; 914 «Витрати на управління виробництвом»; 915 «Інші витрати» [2]. Така пропозиція є обгрунтованою, однак не для сільськогосподарських підприємств, оскільки значну питому вагу їх загальновиробничих витрат становлять витрати на утримання і роботи машинно-тракторного парку, що 


\section{ЕКОНОМІКА}

також належать до непрямих.

Окрема група наукових розробок фахівців 3 обліку стосується удосконалення процесу документування загальновиробничих витрат. Різні автори пропонують розробку форм накопичувально-групувальних відомостей обліку загальновиробничих витрат за групами, напрямами їх понесення, структурними одиницями та зведені відомості. Запровадження таких пристосованих регістрів дасть змогу в оперативному порядку контролювати й управляти процесом понесення витрат на загальновиробничі цілі [2, 3, 6].

Мета і завдання досліджень. Метою дослідження $є$ систематизація існуючих нормативних i концептуальних наукових положень щодо визнання, оцінки, розподілу, облікового відображення загальновиробничих витрат аграрних підприємств у контексті розробки системи формування їх оптимальних розмірів та ефективного управління ними у процесі реалізації найкращих зразків ринкової стратегії підприємства.

Досягнення мети реалізується через наступні завдання:

- проведення структурного аналізу терміну «загальновиробничі витрати» для впорядкування теоретичних наукових уявлень;

- виявлення засад раціональної класифікації таких витрат із метою вибору варіанта подальшого облікового відображення;

- співвідношення порядку визнання означених витрат для цілей фінансового, управлінського податкового обліку;

- формування підходів до вибору оптимальної бази розподілу непрямих витрат 3 урахуванням галузевої специфіки підприємств, що досліджувалися.

Матеріали і методи досліджень. Інформаційним забезпеченням дослідження виступали праці вітчизняних і зарубіжних науковців галузі фінансового, управлінського обліку витрат та їх аналізу. Практичне підтвердження наведені судження отримали засобами дослідження даних обліку та матеріалів звітності значної кількості аграрних підприємств Полтавської області.

У процесі формування матеріалів статті використовувалися загальні методи і прийоми наукового пізнання, фундаментальні положення економічної науки обліку, зосереджені й систематизовані у доробку вітчизняних і зарубіжних дослідників обліково-аналітичного забезпечення витрат. Для аналізу понятійного апарату та структурної побудови основних дефініції використовувався абстрактно-логічний метод пізнання; теоретичні основи формування та розподілу загальновиробничих витрат досліджувалися засобами використання аналізу й синтезу, індукції та дедукції; методи функціонально-логічного аналізу й організаційного моделювання були застосовані на етапі розробки моделей оптимального розподілу загальновиробничих витрат i включення їх до собівартості.

Результати досліджень. Загальновідомим $\epsilon$ факт віднесення загальновиробничих витрат до складу непрямих із подальшим розподілом між видами продукції. Дискусії точаться лише стосовно вибору оптимальної бази для розподілу витрат.

Застосування різних методів і баз розподілу витрат обслуговуючих виробництв призводить до різних значень оцінки витрат основних виробництв та собівартості випущеної ними продукції, до того ж різниця може бути досить суттєвою й зростає зі збільшенням частки непрямих витрат.

Не викликає сумнівів необхідність диференціального підходу до вибору бази розподілу залежно від специфіки галузі та виробничого процесу досліджуваного підприємства. Так, години праці можуть бути використані в якості бази розподілу загальновиробничих витрат для підприємств, у яких немає принципової різниці між розмірами зарплати й вона майже для всіх однакова. Пропорційно до кількості (маси) виготовленої або добутої продукції доцільно розподіляти загальновиробничі витрати в металургії, виробництві будівельних матеріалів, гірничодобувній промисловості. Крім того широко використовуються такі бази розподілу як машиногодини, кошторисні (нормативні) ставки, прямі витрати на оплату праці.

Нині виникає чимало розходжень щодо визначення оптимальної бази для розподілу непрямих витрат саме у сільському господарстві. 3 кількох показників, запропонованих Національними стандартами, жоден не виділяється своєю стовідсотковою точністю й гнучкістю у використанні. Найбільше це стосується рослинництва, що має низку характерних особливостей як галузь із великим впливом на виробництво природо-кліматичних факторів, що у значній мірі визначають розмір виробництва та витрати на вирощування біологічних активів.

У сільському господарстві загальновиробничі витрати рослинництва, тваринництва та промислових виробництв передбачено розподіляти між об'єктами планування й обліку пропорційно загальній сумі витрат, окрім вартості насіння, кормів, сировини, матеріалів та напівфабрикатів.

Теоретики i практики обліку визнають, що вітчизняна система калькулювання собівартості 


\section{ЕКОНОМІКА}

перебуває у проміжному стані між ринковою й плановою методологією й тому П(С)БО 16 «Витрати» [5] передбачає калькулювання повної виробничої собівартості, що на заході позначається терміном «absorption cost» [1].

Облікове відображення віднесення загальновиробничих витрат безпосередньо пов'язано з категорією «нормальна потужність» і віднесенням їх до постійних або змінних за ознакою реагування на зміну обсягу виробництва продукції, робіт, послуг. Якщо фактичний обсяг виробництва:

- менший за нормальну потужність, то до виробничої собівартості включається добуток нормативу постійних витрат на фактичний обсяг виробництва, тобто, до собівартості включається лише частина постійних загальновиробничих витрат: Дт 23 «Виробництво» Кт 91 «Загальновиробничі витрати». Частина постійних загальновиробничих витрат, що залишилася, є нерозподіленою і включається до складу собівартості реалізованої продукції (робіт, послуг) у період їх виникнення: Дт 90 «Собівартість реалізації» Кт 91 «Загальновиробничі витрати»;

- дорівнює нормальній потужності, то вся сума постійних витрат включається до виробничої собівартості продукції: Дт 23 «Виробництво», Кт 91 «Загальновиробничі витрати»;

- більше нормальної потужності, то нерозподілених витрат немає: Дт 23 «Виробництво», Кт 91 «Загальновиробничі витрати». У такому разі загальна сума розподілених i нерозподілених постійних загальновиробничих витрат не може перевищувати їх фактичної величини.

Поділ загальновиробничих витрат на постійні й змінні та їх подальший перерозподіл, очевидно, створює процедурні труднощі для бухгалтерів-практиків.

Спрощення процедурних аспектів включення до собівартості загальновиробничих витрат можливе також за умов переходу на широко застосовувану у розвинених країнах систему калькулювання собівартості винятково за змінними витратами «direct cost», що змістить акцентний наголос зі значення постійних загальновиробничих витрат для процесу калькулювання.

Вирішення потребує також питання щодо включення до собівартості реалізації нерозподілених загальновиробничих витрат за умови відсутності продажу виготовленої продукції. За принципом відповідності доходів і витрат складовою собівартості реалізації нерозподілені загальновиробничі витрати стануть у місяці отримання доходів (виручки), а до цього необхідно накопичувати такі витрати, наприклад, на субра- хунках обліку витрат майбутніх періодів.

Для підприємств із сезонним виробничим циклом актуальне згладжування коливань сумових розмірів загальновиробничих витрат засобами використання облікового інструменту забезпечень (на зразок формування і використання резерву оплати відпусток).

Удосконалення методичних засад розподілу загальновиробничих витрат зменшує дію фактора умовності розподілу й зумовлює у подальшому адекватне облікове відображення.

Суперечності фінансового та управлінського обліків загальновиробничих витрат, зважаючи на гармонізацію нормативних положень П(С)БО 16 «Витрати» та Податкового кодексу, чітко проявляються і у податковому обліку.

Так, одразу після прийняття Податкового кодексу загальновиробничі витрати зараховувалися до інших витрат (пп. 138.10.1) у складі витрат звітного періоду (пп. 138.5) [4 ].

Із 1 серпня 2011 р. загальновиробничі витрати, згідно з Законом України № 3609 від 7.07.2011 p. «Про внесення змін до Податкового кодексу та деяких інших законодавчих актів України щодо вдосконалення окремих норм Податкового кодексу України», стали складовою собівартості виготовленої та реалізованої продукції (робіт, послуг). Нормативні удосконалення зумовили зміну підходів до дати визнання загальновиробничих витрат для цілей оподаткування: як частина собівартості змінні та постійні розподілені загальновиробничі витрати визнаються витратами у періоді визнання доходу від реалізації; постійні нерозподілені - включаються до витрат періоду за фактом їх здійснення, звісно, у складі собівартості реалізації. На практиці це зумовило потребу підприємств на загальній системі оподаткування у перерозподілі цих витрат для цілей складання Декларації з податку на прибуток із 01.04.2011 р. та, відповідно, повторного обчислення собівартості реалізації за період із 1.04.2011 р. до 1.08.2011 року.

Висновок. База розподілу загальновиробничих витрат повинна враховувати причиннонаслідковий взаємозв'язок між непрямими витратами й об'єктами, що є основою для їх розподілу. У виборі бази для розподілу потрібно використати такий показник, який би максимально точно забезпечував віднесення непрямих витрат на відповідні об' єкти калькулювання. Необхідно також враховувати те, що між зміною загальновиробничих витрат і зміною бази розподілу існує пропорційна або майже пропорційна залежність.

У сільському господарстві обсяг виробництва 


\section{ЕКОНОМІКА}

(потужність) залежить також від природних факторів, а не лише від діяльності людей. Тому у сільськогосподарських підприємствах доцільно суму загальновиробничих витрат відносити до витрат основного виробництва, не враховуючи показник «нормальна потужність».

Доцільно виділити два основні періоди щодо розрахунку коефіцієнтів розподілу: рік і місяць. Хоча 3 метою отримання необхідної інформації для прийняття управлінських рішень можна за-

\section{БІБЛІОГРАФІЯ}

1. Довгопол Н. П(С)БО 16 «Витрати» між фінансовим та управлінським обліком / Н. Довгопол, М. Нестеренко // Бухгалтерський облік і аудит. - 2011. - № 6. - С. 3-15.

2. Кодимська Т. Ю. Шляхи покращення обліку та розподілу загальновиробничих витрат на підприємствах [Електронний ресурс] / Т. Ю. Кодимська // Економіка: реалії часу. Науковий журнал. - 2013. № 1 (6). - С. 196-200. - Режим доступу: http://economics.opu.ua/files /archive/2013/n1.html.

3. Мазуренко O. М. Бухгалтерський облік та аналіз загальновиробничих витрат : теорія, методика, організація : Автореф. дис. ... канд. екон. наук : спец. 08.00.09 «Бухгалтерський облік, аналіз та аудит (за видами економічної діяльнос- стосовувати також інші періоди - день, тиждень, квартал і т. д.

Впроваджуючи в практику облікової роботи наукові розробки у даному напрямі не слід забувати, що потенційні вигоди від підвищення рівня якості обліку загальновиробничих витрат засобами деталізації розподілу непрямих витрат повинні перевищувати затрати часу й праці на процедурні аспекти та документування такого розподілу.

ті)» / О. М. Мазуренко. - Житомир, 2010. - 21 с.

4. Податковий кодекс України №2755 від 2 груд. 2010 р. [Електронний ресурс] / Верховна Рада України. - Режим доступу : http:// www.rada.gov.ua.

5. Положення (Стандарт) бухгалтерського обліку 16 «Витрати», затверджений наказом Міністерства фінансів України № 318 від 31 грудня 1999 р. [Електронний ресурс] / Верховна Рада України. - Режим доступу : http : // www.rada.gov.ua.

6. Проданчук М. А. Стратегічний аналіз витрат як основа прийняття оптимальних управлінських рішень / М. А. Проданчук // Економіка АПК. 2012. - № 11. - C. 56-63. 